\title{
TECNOLOGIAS EDUCACIONAIS NO ENADE DO CURSO DE LICENCIATURA EM LETRAS: ANÁLISE DE 2005 A 2017
}

\section{Educational Technologies in ENADE for the Language and Literature Teaching Course: an analysis from 2005 to 2017}

\section{Tecnologías educacionales en el examen ENADE del curso de profesorado en Letras: 2005-2017}

Daíne Cavalcanti da Silva ${ }^{1}$

Glaucia da Silva Brito²

\section{RESUMO}

O foco deste estudo é analisar como são avaliados os professores de língua em formação, no que diz respeito às tecnologias educacionais, nas provas do ENADE (Exame Nacional de Desempenho dos Estudantes) para o curso de Licenciatura em Letras, considerando o contexto da cibercultura. O objetivo do ENADE é verificar o rendimento dos alunos em comparação às diretrizes curriculares do curso. O corpus constituiu-se dos documentos

Submetido em: 18/08/2020 - Aceito em: 05/12/2020 - Publicado em: 24/12/2020

1 Doutoranda em Educação pela Universidade Federal do Paraná - UFPR. Mestre em Educação pela Universidade Federal do Paraná - UFPR. Especialista em Língua Portuguesa e Literatura Brasileira e em Pedagogia Empresarial e Educação Corporativa. Graduada em Letras Português Inglês e respectivas Literaturas pela Universidade Paranaense (2008) e em Pedagogia pelo Centro Universitário Internacional Uninter (2017). Docente de cursos de graduação a distância, principalmente, na área de metodologia de ensino e tecnologias educacionais. A produção trata principalmente dos seguintes temas: tecnologia, livro didático, língua portuguesa, gêneros discursivos, formação de professores e educação a distância.

${ }^{2}$ Graduada em Bacharelado e Licenciatura Português Inglês pela Faculdade de Educação Ciências e Letras de Cascavel (1990), Especialização na Metodologia do Ensino Tecnológico pela Universidade Tecnológica Federal do Paraná (1994), Mestra em Tecnologia pela Universidade Tecnológica Federal do Paraná (1997) e Doutora em Linguística pela Universidade Federal de Santa Catarina. Professora da Universidade Federal do Paraná atuando no Departamento de Comunicação Social e no Programa de Pós-Graduação em Educação da UFPR. Coordena o GEPPETE Grupo de Pesquisa e Estudos, Professor, Escola e Tecnologias Educacionais. 
publicados pelo Instituto Nacional de Estudos e Pesquisas Educacionais Anísio Teixeira (INEP) para a realização das avaliações e das provas aplicadas aos estudantes, nos anos de 2005 a 2017, bem como as diretrizes que norteiam o curso. A base teórica pautou-se em Brito e Purificação (2015), Kenski (2012), Moran, Mazetto e Behrens (2013) e Garcia-Vera (2003), Lévy (2010) e Lemos (2003), tem-se ainda os verbetes do Dicionário crítico de educação e tecnologias e de educação a distância organizado por Daniel Mill (2018). Foi realizada a análise de conteúdo do corpus a partir das categorias criadas, considerando a metodologia proposta por Bardin (2016). Confirmou-se a existência de questões que abordam a temática tecnologias educacionais e que, ao longo dos anos, houve uma preocupação em avaliar o entendimento dos professores de língua em formação para além da inserção de equipamentos nos ambientes de ensino. Percebeu-se ainda um aumento quantitativo e qualitativo ao longo dos anos em relação às questões aplicadas; alguns temas foram incluídos e foi exigido dos licenciandos uma reflexão sobre a relação entre conteúdos e metodologias no ensino de línguas concernente às tecnologias educacionais.

Palavras-chave: Formação de professores de língua portuguesa. Tecnologias educacionais. ENADE. Cibercultura.

\section{ABSTRACT}

The focus of this study is to analyze how language teachers in training are evaluated, in regard to educational technologies, in the ENADE (National Assessment of Students Performance) exam for the Language and Literature teaching programs, considering the context of cyberculture. The purpose of ENADE is to verify the performance of students opposed to the curriculum guidelines of the course. The corpus of this research was composed of the documents published by National Institute of Studies and Educational Research Anísio Teixeira (INEP) to carry out the evaluations and tests applied to students, from 2005 to 2017, as well as the guidelines that guide the course. The theoretical basis was built on Brito and Purificação (2015), Kenski (2012), Moran, Mazetto and Behrens (2013), Garcia-Vera (2003), Lévy (2010), Lemos (2003), and also entries from the Dicionário crítico de educação e tecnologias e de educação a distância (Critical Dictionary of Education and Technologies and Distance Education) organized by Daniel Mill (2018). The content analysis of the corpus was performed based on the categories created, considering the methodology proposed by Bardin (2016). The existence of issues that address the theme of educational technologies was confirmed and, over the years, there has been a concern to assess the understanding of language teachers in training beyond the inclusion of equipment in teaching environments. There was also a quantitative and qualitative increase over the years in relation to the applied issues; some themes were included and teachers in training were required to reflect on the relationship between content and methodologies in language teaching regarding educational technologies. 
Keywords: Portuguese Language teacher training. Educational technologies. ENADE. Cyberculture.

\section{RESUMEN}

En el enfoque de este estudio es analizar de qué manera los docentes que realizan los estudios en la carrera de lengua portuguesa son evaluados, en lo que se refiere al uso de tecnologías educacionales, en las pruebas del examen brasileño ENADE (Examen Nacional de Educación Superior), puntalmente para la carrera de Profesorado en Letras. Se considera, en este análisis, el contexto de la cibercultura. El objetivo del ENADE es verificar el desarrollo del alumnado en comparación a las directrices curriculares de la carrera. El corpus está compuesto de los documentos publicados por el INEP, un instituto brasileño volcado a la educación básica y relacionado con el Ministerio de la Educación, responsable de realizar los exámenes con los estudiantes, entre los años 2005 y 2017, tales cuales las guías que definen la carrera. El marco teórico está basado en Brito y Purificação (2015), Kenski (2012), Moran, Mazetto y Behrens (2013), Garcia-Vera (2003), Lévy (2010) y Lemos. Además de eso, son utilizadas las entradas del Dicionário crítico de educação e tecnologias e de educação a distância, el que fue coordinado por Daniel Mill (2018). El análisis del contenido del corpus fue realizado a través de las categorías creadas, tomando en cuenta la metodología propuesta por Bardin (2016). Ha sido confirmada la existencia de cuestiones que tratan del tema tecnologías educacionales y que, a lo largo de los años, hubo también una preocupación de evaluar el entendimiento de los docentes de lenguas en formación para ejes que van más allá del uso de equipos en los ambientes de enseñanza. Se observó un incremento cuantitativo y cualitativo a lo largo de los años en relación a las cuestiones; fueron agregados temas y les fue exigido a los profesores una reflexión acerca de la relación entre los contenidos y las metodologías en la enseñanza de lengua relacionadas con las tecnologías educacionales.

Palabras-clave: Formación de profesores de lengua portuguesa. Tecnologías educacionales. ENADE. Cibercultura.

\section{INTRODUÇÃO}

A educação está ligada ao que vivemos, às práticas executadas ao longo da vida, às relações que estabelecemos, todas essas atividades refletem um aprendizado constante. Partindo do pressuposto que vivemos em uma sociedade permeada pela tecnologia, a discussão nos cursos de licenciatura é reflexo de uma necessidade apresentada pelo contexto em que estamos inseridos. De acordo com Brito 


\section{Revista Docência e Cibercultura}

e Purificação (2015, p. 22), "quando nos referimos à educação, queremos expressar nosso entendimento de que ninguém escapa a ela. (...) Todos os dias misturamos vida e educação.”

Atrelado ao entendimento de que a tecnologia e a educação são indissociáveis, como explica Kenski (2012), todos os sujeitos envolvidos com o processo de ensinar línguas precisam conhecer, analisar e trazer para sua prática as tecnologias educacionais. Por isso, ao longo dos anos, a discussão sobre tecnologia nos cursos de Letras, nos quais se formam professores que ensinam línguas, têm ganhado espaço, às vezes, como disciplinas específicas, outras, entrelaçada em disciplinas da grade curricular. De acordo com o perfil dos formandos, no parecer das Diretrizes Curriculares para os cursos de Letras, o profissional de Letras "deve ser capaz de refletir teoricamente sobre a linguagem, de fazer uso de novas tecnologias e de compreender sua formação profissional como processo contínuo, autônomo e permanente" (CONSELHO NACIONAL DE EDUCAÇÃO, 2001, p. 30). Corroborando o parecer, o artigo segundo das Diretrizes Curriculares Nacionais para a Formação de Professores da Educação Básica, indica que a formação nas instituições deve preparar para "VI - o uso de tecnologias da informação e da comunicação e de metodologias, estratégias e materiais de apoio inovadores" (CONSELHO NACIONAL DE EDUCAÇÃO, 2002, p.1).

Desta forma, a presente pesquisa tem como mote a avaliação aplicada a professores de língua em formação, no que diz respeito às tecnologias educacionais, considerando o contexto da cibercultura. Para verificar como se dá tal avaliação, optou-se por identificar se, nas provas do ENADE (Exame Nacional de Desempenho dos Estudantes) do curso de Licenciatura em Letras, com habilitação em língua portuguesa, aparece a temática tecnologia, mais especificamente, as tecnologias educacionais. Busca-se ainda analisar se as questões de avaliação do exame permitem uma reflexão sobre a tecnologia educacional que vá além da mera inserção de equipamentos nas aulas.

Desde 2004, o ENADE vem sendo aplicado para alunos dos cursos de graduação buscando a verificação do rendimento em comparação às diretrizes curriculares de seus cursos. De acordo com o INEP (Instituto Nacional de Estudos e Pesquisas Educacionais Anísio Teixeira), instituição responsável pela aplicação do exame, o ENADE prevê ainda a verificação das competências e habilidades para a formação geral e profissional dos estudantes e a atualização dos discentes em relação à realidade nacional e mundial.

O ENADE é parte integrante do Sistema Nacional de Avaliação da Educação Superior, o Sinaes, e em conjunto com a Avaliação de cursos de graduação e a Avaliação institucional “formam o tripé avaliativo que permite conhecer a qualidade dos cursos e instituições de educação superior brasileiras" (INEP, 2019). 
A aplicação do exame ENADE é dividida em anos: I, II e III, sendo o ano II o que avalia os cursos de Licenciatura em Letras, dessa forma, a primeira aplicação para os licenciandos em língua portuguesa foi no ano de 2005, tendo como anos subsequentes de avaliação os exames de 2008, 2011, 2014 e 2017.

O corpus de análise para esta pesquisa foi composto pelos documentos publicados pelo INEP para a realização do ENADE: portarias das diretrizes de formação geral e as específicas do curso de língua portuguesa, bem como as provas aplicadas aos estudantes, tais documentos são referentes aos anos de aplicação de 2005 a 2017. Foram ainda analisadas as Diretrizes Curriculares Nacionais para os cursos de Letras e as Diretrizes Curriculares Nacionais para a Formação de Professores da Educação Básica. Foi realizada uma análise do corpus considerando as categorias criadas com orientação dos estudos de Bardin (2016) sobre análise de conteúdo.

Os pressupostos teóricos pautam-se, inicialmente, nos estudos sobre tecnologia e formação de professores de autores como Brito e Purificação (2015), Kenski (2012), Moran, Mazetto e Behrens (2013) e Garcia-Vera (2003), a temática cibercultura será analisada a partir de Lévy (2010) e Lemos (2003), a base conceitual traz ainda os verbetes do Dicionário crítico de educação e tecnologias e de educação a distância organizado por Daniel Mill (2018).

\section{CONCEITUANDO TECNOLOGIAS}

As portarias do ENADE não trazem conceitos sobre as temáticas abordadas, ao longo da leitura não foi possível compreender, por exemplo, o conceito de tecnologia adotado para elaboração das provas. A exemplo do ENADE, é comum que se apresentem discussões sobre a temática tecnologia sem que se apresente um ponto de partida, um conceito que norteie os debates propostos nesta pesquisa. Para que não se recorra a mesma falta, o presente trabalho elege como conceito-base de tecnologia a definição de Bertoldo e Mill (2018) presente no Dicionário crítico de educação e tecnologias e de educação a distância. Os autores apresentam, dentre outras falas:

Tecnologia é habilidade, conhecimento e objetos (meios e procedimentos racionais) que ampliam a capacidade do homem de manipular e transformar o mundo em que vive. Tecnologia é destreza, astúcia e habilidade prática racional, possibilitada pelo conhecimento que permite ao homem criar os objetos (meios, ferramentas, procedimentos, sistemas e artefatos) necessários à organização, à manipulação e à transformação de matéria, energia e informação segundo sua intenção e seu objetivo. [...] Tecnologia é conhecimento, ou seja, é modelo ou projeto que preexiste no intelecto do artesão e que pode ser avaliado pela adequação das 
soluções alcançadas. Concerne ao inventar de que modo vem a ser o que não existia e, atento, a demanda do usuário e à exigência do contexto, é o estudar (teorizar) a matéria e a forma que, expressas pelo projeto e pelo desenho (seu momento mais acabado), tornam possível fazer, produzir e fabricar de que modo vem a ser (p. 596597).

A partir do conceito de Bertoldo e Mill, entende-se que a tecnologia é muito mais que instrumentos e ferramentas, mas é também conhecimento que proporciona a transformação do mundo.

Ainda em busca das definições basilares e sem a intenção de esgotar as definições da temática tecnologia, cabe apresentar a definição que efetivamente norteia esta pesquisa para a formação e análise do corpus: a de Tecnologia da Informação e Comunicação (TIC).

De acordo com Bertoldo, Mill e Salto (2018), as TICs tiveram um crescimento acelerado no final do século XX, momento em que se destaca "o computador (uma máquina de informação, por excelência)" (p. 620) inserido em uma sociedade que pode ser chamada de "sociedade da informação", "sociedade pós-industrial" ou "sociedade do conhecimento". Para esses autores, as TICs têm três funções fundamentais: “1) as funções de registrar ou gravar; 2) as funções de comunicar; e 3) as funções de elaborar ou registrar a informação" (BERTOLDO, MILL e SALTO, 2018, p. 620). Ainda que toda a discussão proposta seja profícua e mereça ser estudada a finco, avança-se para a relação estabelecida com a educação, objetivo desta pesquisa.

A partir da primeira função exposta: registrar ou gravar, surge a "digitalização e virtualização", em que diversas informações podem ser reescritas, armazenadas, reorganizadas e disponibilizadas em uma velocidade muito maior; os pesquisadores deixam claro que, ainda que haja uma mudança, essa não significa uma substituição de formas anteriores de acesso e armazenamento da informação; essa mesma acepção, reconfiguração e não substituição, poderá ser vista dentre as leis da cibercultura trazida pela voz de Lemos (2003) mais adiante neste estudo. No que tange à educação, os autores afirmam que o processo de digitalização e virtualização potencializou as novas formas de armazenamento da informação de modo que ofereceu

uma nova gramática e semiologia e, em educação, novas formas de letramento e educação, refletidas na passagem do aluno consumidor passivo de informação ao aluno autor autônomo; do texto ao hipertexto e à hipermídia; das imagens estáticas às animações e às simulações; da educação presencial à educação a distância; da construção solitária do conhecimento às redes de interação e colaboração; da inteligência individual à coletiva (BERTOLDO, MILL e SALTO 2018, p. 622). 


\section{Revista Docência e Cibercultura}

Sobre as TICs, Kenski (2012, p. 28) as conceitua da seguinte maneira: "baseado no uso da linguagem oral, da escrita e da síntese entre som, imagem e movimento, o processo de produção e o uso desses meios compreendem tecnologias específicas de informação e comunicação, as TICs.”

A partir das falas de Bertoldo, Mill e Salto (2018), Kenski (2012) e os conceitos de cibercultura que serão apresentados, considera-se como TICs as ferramentas e os recursos tecnológicos ligados à cibercultura que permitem a interação entre pessoas e máquinas, pessoas e pessoas, máquinas e máquinas. Considera-se ainda como TICs as ferramentas e recursos que permitem o compartilhamento de informações de forma descentralizada dos meios de comunicação de massa, bem como as possibilidades de armazenamento de informações a partir do uso de equipamentos ligados à internet. Dada a gama de definições que se tem de tecnologia e pensando na montagem do corpus, que é baseado na avaliação de alunos de um curso de formação de professores, é necessário que se traga o que se compreende por tecnologia educacional no presente estudo.

Assim como a definição de tecnologia, a de tecnologia educacional também é amplamente discutida. De acordo com Brito e Purificação (2015, p. 56), "tecnologias na educação são todos os artefatos que fazem parte da realidade de muitas escolas do nosso país e que são utilizados no processo de ensinoaprendizagem."

Considerando as falas das autoras e as de Bertoldo e Mill, afirma-se que o quadro negro, o rádio e a televisão, quando usados no processo de ensino-aprendizagem, são tecnologias educacionais, porém, ainda que esses e vários outros recursos sejam usados na prática pedagógica do docente, ressalta-se que a presença deles durante as aulas não garante a eficácia do processo, mudança metodológica, tão pouco um avanço ou melhoria no ensino.

\section{PRESSUPOSTOS METODOLÓGICOS}

O presente estudo, como dito anteriormente, teve como corpus de análise as portarias e as provas do ENADE, constituindo-se assim, em uma pesquisa documental. De acordo com Gil (2008, p. 147), "a pesquisa documental tradicionalmente vale-se dos registros cursivos, que são persistentes e continuados. Exemplos clássicos dessa modalidade de registro são os documentos elaborados por agências governamentais", podendo o corpus ser categorizado ainda, segundo o mesmo autor, como "registros institucionais escritos". 


\section{Revista Docência e Cibercultura}

A análise do corpus de pesquisa pautou-se nas orientações de Bardin (2016), para ela, a análise de conteúdo é dividida em três etapas cronológicas: "a pré-análise, a exploração do material e o tratamento dos resultados, a inferência e a interpretação" (p. 125).

A etapa de pré-análise tem como objetivo organizar a pesquisa. Neste estudo, essa etapa foi realizada no site do ENADE, na página do INEP. A partir de uma leitura flutuante, verificou-se quais eram os principais documentos norteadores do ENADE do curso de licenciatura em Letras com habilitação em língua portuguesa, bem como as provas que foram aplicadas desde a primeira edição, em 2005.

Uma das etapas da pré-análise é a escolha de documentos que, de acordo com Bardin (2016), tem por objetivo selecionar documentos que forneçam informações para a pesquisa, de modo que possa ser respondido o problema. Em se tratando ainda da escolha de documentos para a formação do corpus, percebeu-se que o INEP disponibilizava um documento intitulado padrão de resposta para cada edição do exame, esse documento trazia o que era esperado em cada uma das respostas discursivas. Esses textos passaram, então, a compor o corpus da pesquisa. A inclusão de tais documentos se deu de forma a atender a regra da exaustividade, proposta por Bardin (2016), no que diz respeito à préanálise. A regra da exaustividade indica que: "não se pode deixar de fora qualquer um dos elementos por esta ou aquela razão (dificuldade de acesso, impressão de não interesse), que não possa ser justificável no plano do rigor" (p. 126-127).

Tendo finalizado a composição do corpus, deu-se continuação ao percurso da pesquisa com a realização da exploração do material. De acordo com Gil (2008, p. 152)

A exploração do material constitui, geralmente, uma fase longa e fastidiosa que tem como objetivo administrar sistematicamente as decisões tomadas na pré-análise. Refere-se fundamentalmente às tarefas de codificação, envolvendo: o recorte (escolha das unidades), a enumeração (escolha das regras de contagem) e a classificação (escolha de categoria).

Após o download de todos os documentos, o corpus então foi importado para o software Atlas.Ti versão 8.4 , onde foi realizada a análise.

É importante ressaltar que um software de análise não faz análises do corpus, de acordo com Saldanha (2016) a responsabilidade de análise ainda está no pesquisador que precisa, assim como na análise manual, compreender os fundamentos de uma análise. Para o autor, o software organiza os dados para que o pesquisador possa fazer suas análises e reflexões. 
A etapa de exploração do material realizada por meio do software Atlas.Ti considerou o objetivo da pesquisa: verificar como é avaliada a temática tecnologia nas provas do ENADE. Para isso, realizou-se o que Bardin (2016) apresenta como inventário, momento em que os elementos do texto são isolados para posterior classificação, que é o segundo momento.

$\mathrm{Na}$ etapa de inventário, foram lidas as portarias para o curso de Letras e as de formação geral do ENADE, dos anos de 2005 a 2017, anos de avaliação do curso. Para inventariar o corpus durante a leitura, foram destacados os trechos que tratavam da temática tecnologia da informação e comunicação, considerando os conceitos elencados na introdução deste estudo. Ressalta-se que, embora o software permita que se faça a busca por palavras, uma pesquisa lexical, optou-se pela leitura na íntegra de todos os documentos. Essa escolha se deu para que fossem identificados outros termos relacionados à temática, como os termos "redes sociais" e "inclusão digital" e para que se pudesse familiarizar com a estrutura das portarias, assim facilitando a etapa seguinte: a da classificação dos elementos.

Nessa etapa da pesquisa, foram elencados os trechos das portarias que abordavam a temática pesquisada, todas as citações foram categorizadas de acordo com os próprios itens presentes nos documentos. A classificação das citações das portarias resultou em 11 (onze) códigos, que estão apresentados no Quadro 1:

Quadro 1 - Códigos criados a partir das portarias do ENADE

\begin{tabular}{|l|}
\hline Avanços/inovações tecnológicos \\
\hline Ciência, tecnologia e sociedade \\
\hline Conhecimento das TIC \\
\hline Inclusão/exclusão digital \\
\hline Multiletramento \\
\hline Multimodalidade \\
\hline Redes sociais \\
\hline Uso das TIC \\
\hline Uso das TIC para o ensino \\
\hline Uso das TIC para o ensino de língua portuguesa \\
\hline Uso das TIC para pesquisa \\
\hline \multicolumn{1}{|c|}{ Fonte: dados da pesquisa (2019). }
\end{tabular}

A partir da categorização das portarias, foi dado início à análise de conteúdo das provas do ENADE. Tal análise se deu pela leitura das provas na íntegra. Durante a leitura foram identificadas 20 (vinte) 
questões que estão no escopo desta pesquisa para que fossem categorizadas a partir dos códigos apresentados no Quadro 1.

No decorrer da categorização, foram percebidas questões que trataram de temáticas não mencionadas explicitamente nas portarias, por isso, fez-se necessária a criação de novas categorias na análise. São elas: cibercultura, tecnologia e EAD e tecnologia como pretexto, sendo esta última relacionada a textos que têm por temática a tecnologia, mas que foram usados como pretexto para o ensino de gramática, sem considerar o tema do texto apresentado.

Assim, na análise das questões, considerando os códigos emergentes das portarias e das questões do ENADE, foram encontradas as categorias mencionadas na Figura 1:

Figura 1 - Categorias dos exames de 2005 a 2017

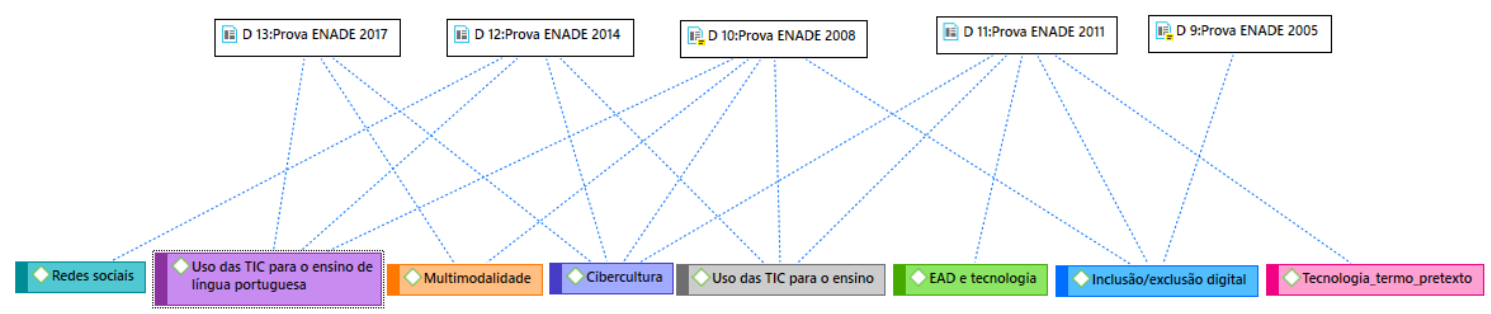

Fonte: dados da pesquisa usando Atlas.ti versão 8.4 (2019).

No próximo item, serão apresentados os resultados e discussão das análises das questões das provas de 2005 a 2017 que abordam a temática tecnologia. A discussão será pautada nos conceitos já apresentados na introdução, nas teorias que embasam as criações e no confrontamento das informações presentes nas portarias do ENADE e em outros documentos que forem necessários para o constructo teórico deste estudo.

\section{ANÁLISE DAS PROVAS DO ENADE DO CURSO DE LETRAS}

Para apresentação das análises das questões presentes no ENADE ter-se-á como ponto de início as categorias apresentadas no Quadro 1 e que foram identificadas nas questões, conforme Figura 1. Para a montagem da Figura, seguiu-se a sequência dos anos de aplicação das provas. Sendo assim, foram inseridas as categorias da prova de 2005: inclusão/exclusão digital, que também estava presente nos exames de 2008 e 2011; depois foram adicionadas as categorias de 2008: multimodalidade (que 
também aparece na prova de 2017) e uso das TICs para o ensino de língua portuguesa (presente também nas provas de 2011, 2014, 2017), o mesmo procedimento foi realizado para todas as provas até que se chegasse à rede apresentada na Figura 1.

A primeira categoria exposta Inclusão/exclusão digital apareceu em quatro questões, sendo duas questões na seção formação geral em 2005, uma discursiva e uma objetiva; uma questão objetiva na seção de formação específica no ano de 2008 e uma questão objetiva na seção de formação geral no ano de 2011. A categoria Inclusão/exclusão digital foi criada a partir das portarias do ENADE por ser um dos possíveis temas da prova do componente de formação geral.

Brito e Purificação (2015, p. 46), ao falarem sobre a inclusão digital do professor, afirmam que “apenas ligar e desligar um equipamento não implica uma verdadeira inclusão digital.” A partir dessa afirmação, é possível analisar a questão do componente de formação específica da categoria Inclusão/exclusão digital. A questão apresenta como elemento-base um texto que aborda novas e velhas tecnologias. Uma das afirmativas a serem analisadas exige do aluno, participante do exame do ENADE, conhecimento sobre o que é inclusão digital conforme pode ser visto na Figura 2.

Figura 2 - Questão de prova: ENADE 2008

\section{QUESTÃO 21}

Antes de compreender o que significam as inovaçø̄es tecnológicas, temos de refletir sobre o que são velhas e novas tecnologias. O atributo do velho ou do novo năo está no produto, no artefato em si mesmo, ou na cronologia das invençס̊es, mas depende da significaçăo do humano, do uso que fazemos dele.

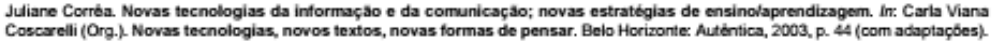

Relacionando as idéias do fragmento de texto acima à formaçăo e à açăo do professor em sala de aula, conclui-se que

( a chegada das inovaçőes tecnológicas à escola torna obsoletos os saberes acumulados pelo professor.

B as inovaçőes tecnológicas no campo do ensino-aprendizagem năo garantem inovaçōes pedagógicas.

○ a inclusăo digital é assegurada quando as escolas săo equipadas com computadores e acesso à Internet.

- os novos modos de ler e escrever no computador devem ser transpostos para a modalidade escrita da língua no espaço escolar.

๑ 0 acervo impresso das bibliotecas escolares deve ser substituido por acervos digitais, de maior circulaçăo e funcionalidade.

Fonte: INEP (2008c, p. 10).

A questão atende a um dos objetivos traçados para o exame, ao "avaliar o desempenho em termos de competências e habilidades essenciais ao exercício profissional, crítico, criativo, ético e cidadão na área de Letras" (INEP, 2008b, p. 2), pois, é essencial que o futuro professor compreenda que a inserção de equipamentos na escola, bem como o uso deles durante o processo de ensino-aprendizagem, não promoverá inovação pedagógica, como consta no distrator $\mathrm{C}$ da questão apresentada. 


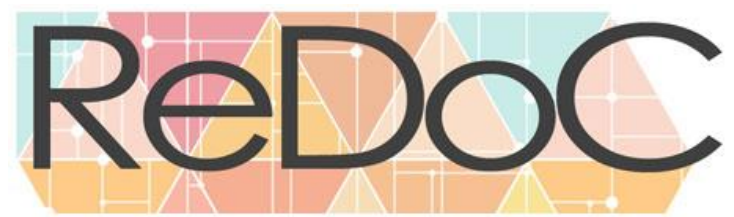

Revista Docência e Cibercultura

Para a análise das três outras questões da categoria, convém apresentar um conceito de inclusão e de exclusão digital para que se possa fundamentar as análises, para Fernandes e Braga (2018, p. 333, grifo das autoras)

Inclusão digital designa a condição daqueles que têm acesso frequente ou facilitado a computadores e à internet, como a outros equipamentos de tecnologias de informação e comunicação (TICs) e possuem habilidades para usá-los de forma autônoma e crítica para busca e tratamento da informação, utilização de serviços on-line, comunicação, entretenimento, educação e produção de conteúdos, entre outras possibilidades, tendo em vista a sua inclusão social. A exclusão digital indica, em contraste, a condição daqueles que se encontram alijados do acesso e da utilização autônoma dessas tecnologias digitais e seus benefícios por elas possibilitados.

As mesmas autoras ainda abordam a importância de a inclusão digital estar associada à inclusão social, essa afirmação fundamenta a questão apresentada na Figura 3 em que se exige do aluno a análise de dois textos que abordam a inclusão digital à inclusão social.

Figura 3 - Trecho de questão de prova: ENADE 2005

2. Leia e relacione os textos a seguir.

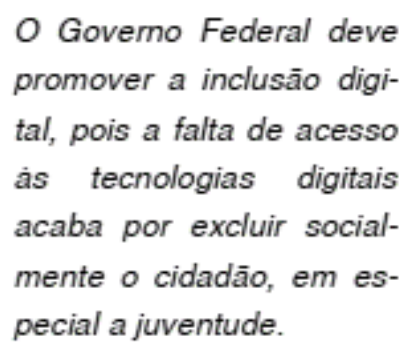

(Projeto Casa Brasil de inclusaao digital começa em 2004. In: MAZZA, Mariana. JB online.)

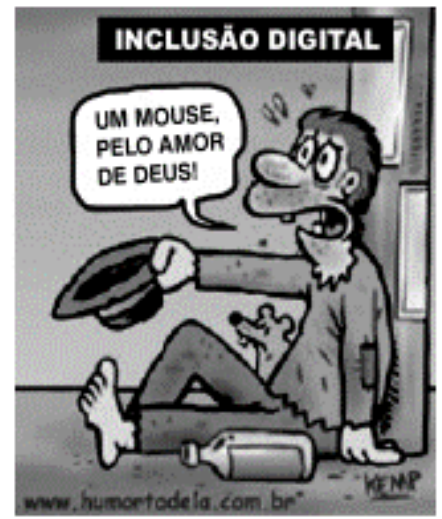

Fonte: INEP (2005c, p. 2).

A associação entre inclusão e exclusão digital também é tema de duas outras questões (Figuras 4 e 5). Nas três questões do componente de formação geral o aluno em avaliação precisa fazer uso de algumas das habilidades indicadas nas diretrizes do exame como analisar, criticar, estabelecer relações e fazer comparações. 
A Figura 4 apresenta uma questão discursiva que expõe uma situação-problema sobre novas tecnologias e trabalho. O comando da questão solicita conclusões considerando os gráficos com dados de acesso à internet no Brasil comparado a outros países.

Figura 4 - Questão de prova: ENADE 2005

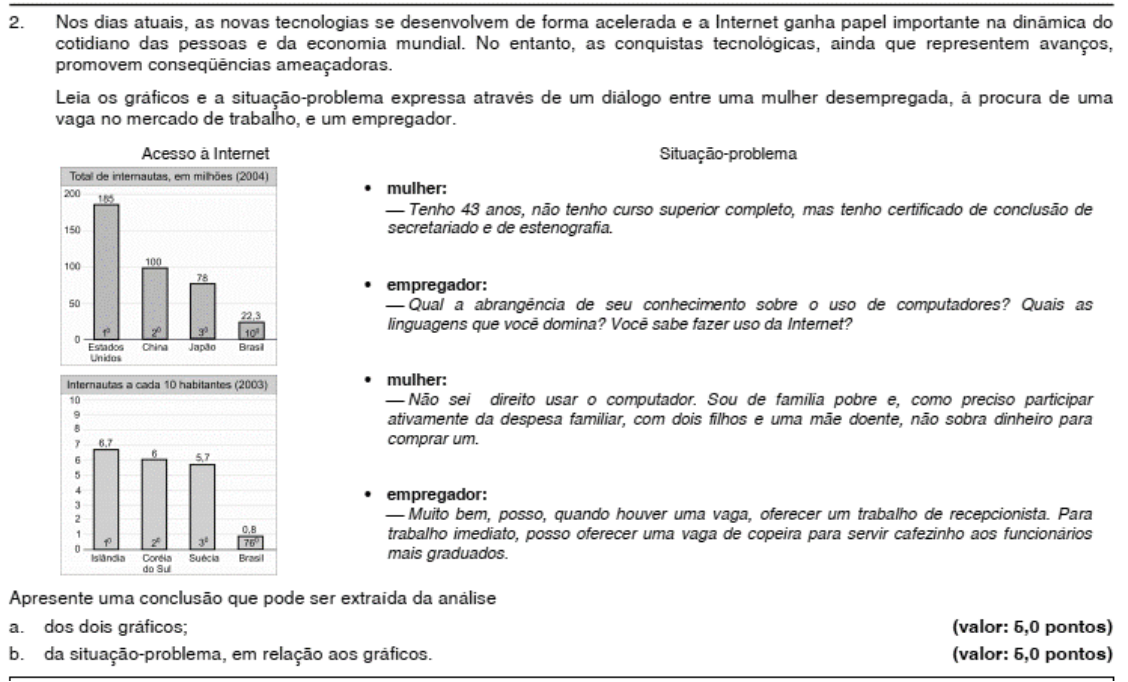

FONTE: INEP (2005c, p. 5).

No documento padrão de respostas, fornecido pelo INEP, para a resposta $b$ são apresentadas soluções que exigem do aluno uma análise e argumentação mais crítica em relação ao tema inclusão e exclusão digital, umas das soluções apresenta: "no mundo atual, a camada mais pobre da população precisa, além de outros fatores, se preocupar com mais um obstáculo para ter uma vida digna: a exclusão digital" (INEP, 2005a, p. 3).

Ainda que as questões das Figuras 3, 4 e 5 sejam da seção de formação geral, não é possível desvinculá-las do processo de formação de professores, como expõe Garcia-Vera (2000), que considera que a formação de professores para novas tecnologias precisa ter em seu currículo três temas relacionados às dimensões: econômico-laboral, político-governamental e sociocultural.

As três dimensões estão ligadas aos conteúdos dessas questões, na Figura 5, por exemplo, a afirmativa II trata da tecnologia e o papel social, atrelando o acesso à mobilidade social e econômica o que em uma análise a partir de Garcia-Vera (2000) pode ser entendida como conhecimento da dimensão econômico-laboral.

A dimensão econômico-laboral prevê que os professores conheçam os conflitos que geram a divisão entre patrões e empregados e que reconheçam o conhecimento como um elemento de poder, 
compreendendo que há relação entre a divisão social no mundo do trabalho e a divisão no mundo social.

Já a dimensão político-governamental indica que os professores precisam conhecer como os governos lidam com a questão do mundo do trabalho, conhecendo as políticas e as formas como legisla e regula os processos, essa dimensão pode ser vista, por exemplo, na afirmativa I da questão apresentada na Figura 5.

Figura 5 - questão de prova: ENADE 2005

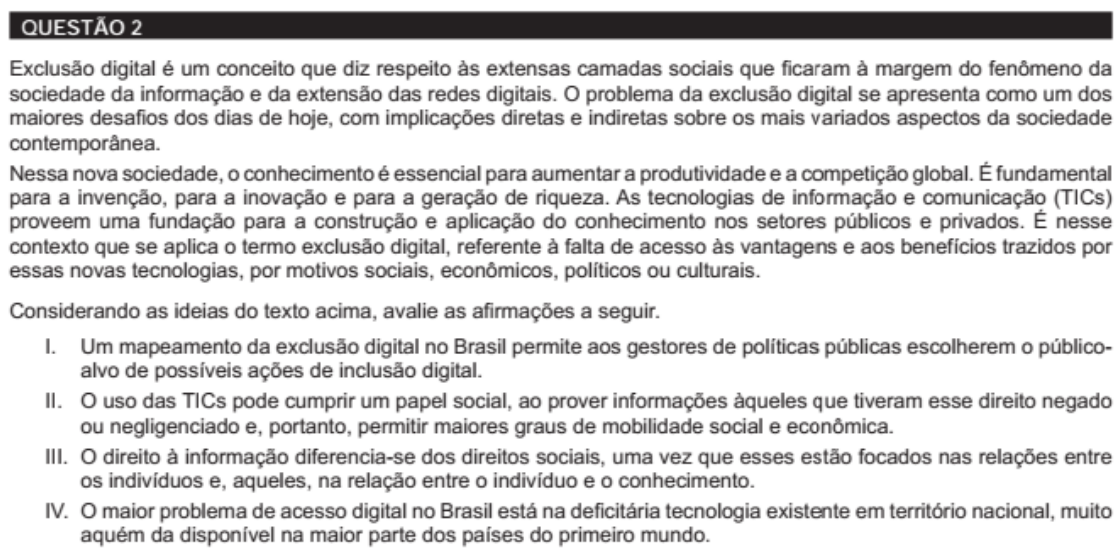

Fonte: INEP (2011d, p. 2).

A dimensão sociocultural está atrelada ao fato de que as pessoas fazem uso de recursos tecnológicos, quando dispõem deles, e os incorporam a suas vidas modificando as formas como realizavam algumas atividades, bem como "suas maneiras de se relacionar com os meios natural, social e cultural" (GARCIA-VERA, 2000, p. 182, tradução nossa) ${ }^{3}$. Essa última dimensão pôde ser vista na charge que é um dos elementos-base apresentado na questão da Figura 3, o mouse é uma dessas ferramentas que passou a fazer parte do cotidiano das pessoas e ali simboliza a inclusão/exclusão digital.

A partir da análise desta categoria, pôde-se inferir que as questões de formação geral também têm sua função avaliativa que permitem verificar o conhecimento do aluno em temáticas que contribuem para a formação docente, conforme exposto por Garcia-Vera ao indicar a necessidade de os futuros professores conhecerem as três dimensões citadas.

Dando continuidade nas análises das questões, temos a categoria multimodalidade, que apareceu em duas questões objetivas nos anos de 2008 e 2017, sendo as duas na seção de formação específica.

\footnotetext{
${ }^{3}$ Sus maneras de relacionarse con su médio, natural, social y cultural.
} 
O termo multimodalidade, de acordo com o Corrêa e Coscarelli (2018), vem sendo usado quando associado a textos que estão organizados a partir do uso de características não verbais, ou seja, vão além do oral e/ou do escrito fazendo uso de sons, imagens e outras sensações, como, por exemplo, as texturas, cheiros e formatos dos livros infantis. Vale ressaltar que, embora o termo tenha ganhado maior visibilidade quando se refere aos textos digitais, as autoras recordam que as inscrições rupestres já apresentavam, nas paredes das cavernas, imagens de animais, figuras humanas, com cores e formas que podem ser compreendidas como um tipo de texto multimodal.

A Figura 6 apresenta uma questão que no enunciado solicita a análise de um folheto "que utiliza tecnologias diversificadas". Dado o fato, já mencionado, de que em nenhum momento se apresenta o que é tecnologia e a diversidade de definições para o tema, optou-se por incluir a questão na categoria multimodalidade. Esta escolha pauta-se nas definições de Corrêa e Coscarelli, pois o texto do folheto a ser analisado vai além do sistema linguístico: traz imagens, cores, remete a uma profundidade na imagem e ainda apresenta o que os autores denominam de "saliências textuais" (2018, p. 468), que seriam os textos verbais escritos em fontes de cores e tamanhos diferentes, como apresentado no texto.

Figura 6 - Trecho de questão de prova: ENADE 2008

\section{QUESTÃO 19}

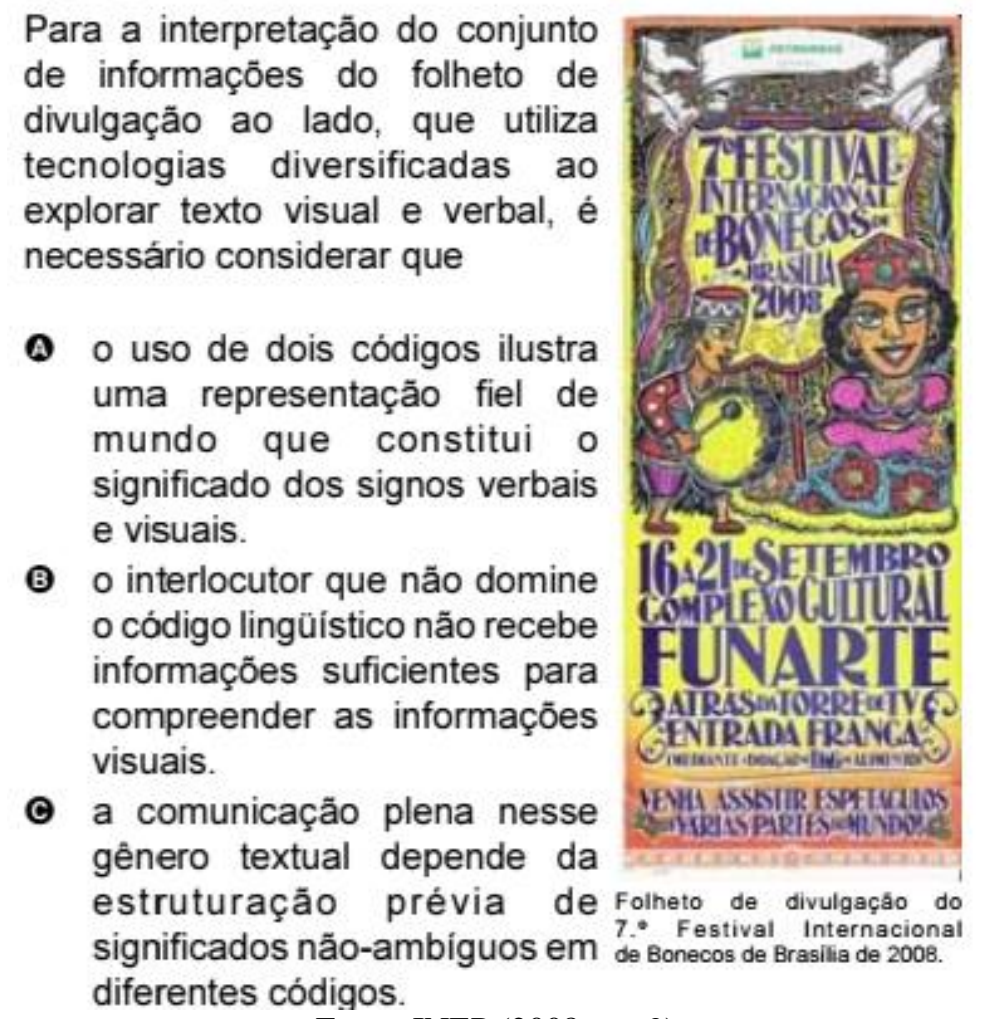

Fonte: INEP (2008c, p. 9). 
De acordo com a portaria do ENADE 2017, a prova avalia, dentre outras competências, se o estudante concluinte é capaz de "identificar e explorar textos multimodais em diferentes ambientes tecnológicos" (INEP, 2017, p. 2), essa competência é avaliada nas próximas questões dessa categoria, na Figuras 7 e 8. Na Figura 7, o conhecimento sobre multimodalidade é exigido nas afirmativas da questão de modelo asserção e razão, pois é necessário que o aluno compreenda que o conceito de multimodalidade vai além das formas de interação na rede.

Figura 7 - Questão de prova: ENADE 2017

QUESTÄO 16

A informaçăo e os conteúdos transbordam na web e o prefiwo hiper, também aí, é demandado. Nesse contexto de hiperinformaçăo, as açŏes de seguir, curtir, taguear e comentar ganham destaque.

O ato de seguir alguém, alguma publicação ou instituiçăo é, entre outras possibilidades, uma forma de filtrar algo de interesse no meio de um oceano de conteúdo.

Frente ao que se segue (ou ao que é de alguma forma publicado) na rede, é possível ter diferentes niveis de resposta: algumas acessíveis diretamente a quem publica o conteúdo - curtir, comentar, rkdistribuir (sem comentar), redistribuir com comentário fundamentado (redistribuiçăo crítica) etc; outras năo tăo diretamente acessiveis - publicaçőes em outras redes ou espaços sem referências diretas às origens.

ROJO, R.; BARBOSA, 1. P. GAneros do discurso, multiletramentas e hicermedernidade. In: Hipermodernidade, multiletramemtos e gêneros discursives. SSo Raulo: Pratbola, 2015 (adaptado).

Considerando as informaçð̄es apresentadas no texto, avalie as asserçס̃es a seguir e a relaçăo proposta entre elas.

I. Na web, os diferentes níveis de publicações/respostas acessiveis, direta ou indiretamente, a quem publica o conteúdo podem ser multimodais.

\section{PORQUE}

II. As publicaç̋̄es/respostas, além de poderem se basear em outros textos, podem ser acrescidas de diferentes tipos de linguagens, como imagens, videos e áudios.

Fonte: INEP (2017d, p. 25)

Já a Figura 8 apresenta em seu elemento-base o conceito de multimodalidade e solicita que os futuros professores reflitam sobre a prática docente em relação aos textos multimodais também em uma questão de modelo asserção e razão. 


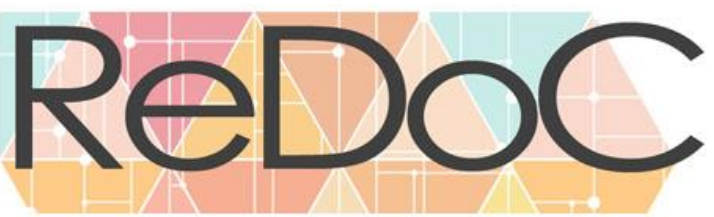

Revista Docência e Cibercultura

Figura 8 - Trecho de questão de prova: ENADE 2017

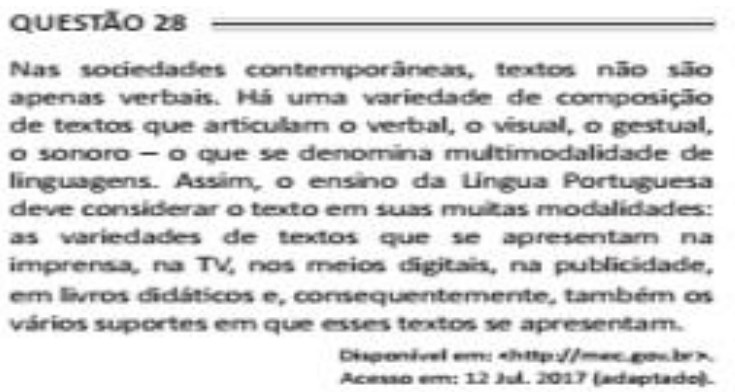

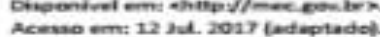

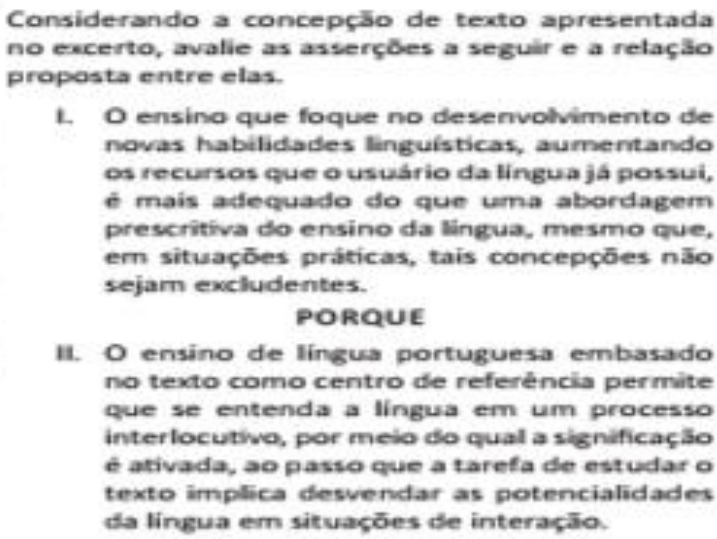

Considerando a concepç̄o de texto apresentada no escerto, avalie as asserçbes a segulir e a relaçlo propasta entre elas.

L. O ensino que foque no desenvolvimento de novas habilidades linguisticas, aumemtando os recursas que o usubrio da lingua ja possui. o mais adequado do que uma abordagerm prescritiva do ensino da lingua, mesmo que, ern situaçōes práticas, tais concepç̄es nāo sejam excludentes.

$$
\text { PORquE }
$$

H. O ensino de lingua portuguesa embasado no texto como centro de referéncia permite que se entenda a lingua em um processo interlocutivo, por melo do qual a significaça é ativada, ao passo que a tarefa de estudar o texto implica desvendar as potencialidades da lingua em situaşös de interaçio.

Fonte: INEP (2017d, p. 35)

A questão exposta na Figura 8 também pertence à próxima categoria de análise Uso das TIC para o ensino de língua portuguesa

As asserções I e II são corretas embora uma não justifique a outra. Na asserção I espera-se que o aluno compreenda que o "desenvolvimento de novas habilidades linguísticas" está relacionado à multimodalidade que, assim como na questão apresentada na Figura 6, e também vista nos teóricos Corrêa e Coscarelli (2018) não está apenas ligada ao digital, mas sim, às características multissemióticas do texto.

A categoria uso das TICs para o ensino de língua portuguesa apareceu em quatro questões, todas na seção de formação específica, sendo uma discursiva no ano de 2008 e uma no ano de 2014 e duas objetivas no ano de 2017, dentre elas a já apresentada na Figura 8.

A questão discursiva apresentada na Figura 9 discute as vantagens e desvantagens das diferentes tecnologias e as relações entre oralidade e escrita, considerando os saberes e as implicações para o ensino-aprendizagem da língua a partir de dois textos sobre o surgimento de tecnologias. 


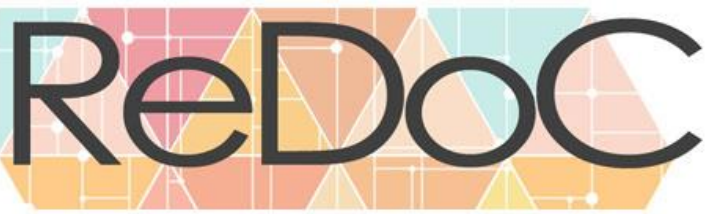

Revista Docência e Cibercultura

Figura 9 - Trecho de questão de prova: ENADE $2008^{4}$

\section{QUESTÃO 40 - DISCURSIVA}

Entre o surgimento da linguagem humana e o da escrita, sucederam-se 1.400 geraçōes. No intervalo de vida de uma geração, cerca de vinte anos, novos paradigmas tecnológicos são inventados reinventados.

Com base no fragmento de texto acima e no infográfico ao lado, desenvolva um dos tópicos a seguir, de acordo com a habilitaçâo do seu curso.

\section{B LICENCIATURA}

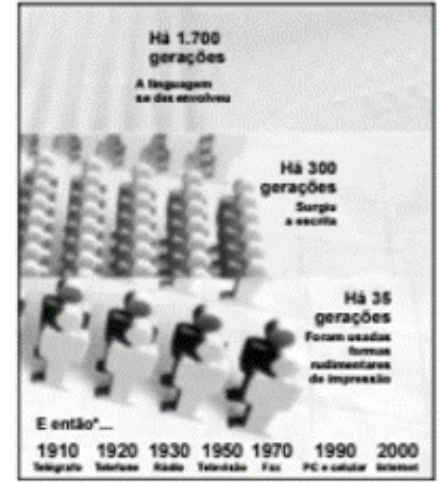

Vantagens e desvantagens das diferentes tecnologias que permeiam as relaçōes entre oralidade e escrita, sob o ponto de vista da prática pedagógica, abordando, necessariamente, os seguintes aspectos:

- o aumento da complexidade dos saberes envolvidos;

- as implicaçōes para o ensino-aprendizagem de língua.

FONTE: INEP (2008c, p. 18).

A questão solicita que sejam considerados os saberes, que é um dos temas debatido pelo filósofo Pierre Lévy (2010). Para ele, a reflexão sobre a educação e a formação na cibercultura deve ser pensada a partir da ideia de mudança em relação ao saber. Uma das constatações apresentadas é de que as competências que um profissional aprende no início da carreira já estarão obsoletas quando chegar ao fim da sua vida profissional. Outra constatação de Lévy diz respeito às tecnologias intelectuais que modificam as condições cognitivas humanas: a memória, a imaginação, a percepção e os raciocínios, nessa última constatação, destacam-se a forma de acesso às informações, como o hipertexto, e novos estilos de conhecimento e raciocínio (2010, p. 159).

Ao contrário do que é apresentado no padrão de resposta da prova de 2005, a prova de 2008 não traz informações sobre as possibilidades de resposta, há apenas uma explanação do comando dado. No que diz respeito às implicações para o ensino-aprendizagem da língua, segunda questão a ser abordada pelos alunos (Figura 9), o acesso à informação por meio de hipertexto pode ser um dos temas citados. Nesse caso, o aluno poderia discorrer sobre os hipertextos relacionados à multimodalidade, conforme conceito apresentado anteriormente, ou ainda, sobre as formas de interação na cibercultura, discutindo sobre os papéis do escritor e do leitor. Para Magda Soares (2002), a relação entre esses dois sujeitos trouxe mudanças significativas na forma como interagem a partir do novo espaço de escrita: a tela.

\footnotetext{
${ }^{4} \mathrm{~A}$ imagem da questão foi recortada e posicionada para melhor visualização, não houve alteração no conteúdo, tendo sido retirada apenas o comando da habilitação de Letras-Bacharelado.
} 
Ainda sobre a cultura da tela a autora menciona a alteração no controle da publicação, pois já se pode publicar e distribuir sem que se passe pelo crivo de editores e revisores, por exemplo.

A afirmação de Soares (2002) é corroborada pelo elemento-base da questão seguinte, apresentada na Figura 10, que traz um texto de Roxane Rojo, que aborda um processo de curadoria a partir de uma playlist comentada. $\mathrm{O}$ comando da pergunta questiona o aluno sobre a prática do professor de língua portuguesa a partir dos gêneros discursivos e os ambientes digitais.

Figura 10 - Trecho de questão de prova: ENADE 2017

Uma ploylist comentada conta com texto de apresentação, que descreve ou relata algo erwolvendo as produçōes em questão, e trechos apreciativos, que podem envolver argumentação, contemplando assim diferentes sequências textuais. Além disso, supōe a produçāo de um roteiro e sua leitura oral/falada, o que requer observar a adequação da linguagem oral, tendo em vista as condiçōes de produção dadas. Em termos de açōes, práticas e procedimentos próprios da wob, a produçāo de uma ploylist comentada permite vivenciar o papel do curador: alguém que seleciona exemplares entre muitos, no caso músicas ou cançōes, a partir de algum critério, organiza-os de determinada forma e destaca, a respeito das cançōes escolhidas ou de seus autores ou executores, algo para comentar. Além disso, supōe a escrita de um roteiro e o manuseio de um editor de áudio. Pode também supor a disponibilização desse arquivo na internet, o que poderia ensejar açōes de curtir e/ou redistribuir.

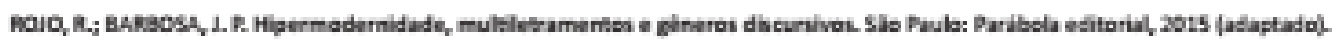
No texto apresentado, mencionam-se algumas açōes, práticas e procedimentos comuns em ambiente digital. Considerando que tais informaçōes permitem que o trabalho do docente de Lingua Portuguesa favoreça a reflexão sobre gênero discursivo e ambiente digital, avalie as afirmaçōes a seguir, acerca do uso de ploylist em sala de aula.
\end{abstract}

1. Atividades de reescritura de sequéncias textuais semelhantes ou differentes voltadas para o uso podem enriquecer a compreensīo do género ploylist comentada.

II. A andise da estrutura de uma playlist comentada favorece a abordagem de caracteristicas que revelem as aproximaçōes e os distanciamentos entre textos orais e escritos.

III. A playlist comentada, enquanto recurso didático, permite a análise de diferentes tipos de argumentação utilizados em ambiente digital.

Fonte: INEP (2017d, p. 37).

No elemento-base, quando se aborda a redistribuição do texto e sobre a organização de um roteiro e manuseio de um editor de áudio, tem-se a representação da cibercultura, categoria que ainda será discutida.

A Figura 11, tem como temática tanto o saber cognitivo, no elemento-base, como o processo de formação de professores, nas questões que devem ser respondidas na produção do texto dissertativo. Para essa questão, o documento de Padrão de resposta, disponibilizado pelo INEP, indica que o aluno deve contextualizar as tecnologias na sociedade relacionando à formação de professores. Em relação à formação de professores, os alunos devem mencionar, pelo menos, dois efeitos, como: a promoção da autonomia do aluno e a facilitação do diálogo entre professores e alunos. 


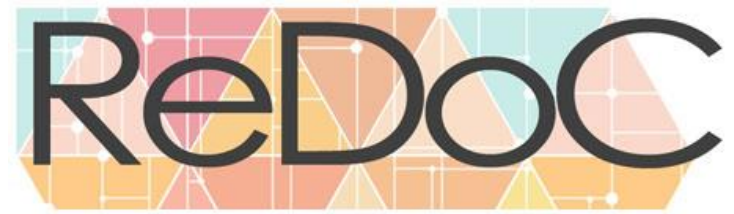

Revista Docência e Cibercultura

Figura 11 - Questão de prova: ENADE $2014^{56}$

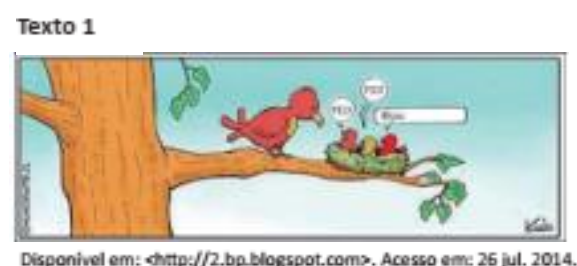

Texto 2

As tecnologias informáticas, consideradas novos sistemas para tratar e representar a informação, ancoradas nos sistemas convencionais, vāo modificar o modo como as crianças estāo habituadas a aprender e também amplificar o seu desenvolvimento cognitivo.

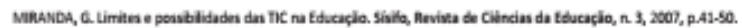

Com base nesses textos, redija um texto dissertativo abordando os seguintes aspectos:

a) necessidade de continua formação profissional do futuro professor de lingua em um mundo cada vez mais tecnológico; (valor: 5,0 pontos)

b) efeitos da contínua formação profissional do professor na prática escolar. (valor: 5,0 pontos)

Fonte: INEP (2014d, p. 13).

Na perspectiva de contextualizar tecnologia e sociedade e os efeitos na prática escolar a partir da formação de professores, pode-se fundamentar que a questão poderia ser respondida a partir das concepções apresentadas por Moran, Masetto e Behrens (2013). Para eles, assim como para outros autores aqui já apresentados, o que define a aprendizagem são as pessoas, sendo assim, a inclusão de equipamentos na escola, não modifica, necessariamente, o processo de ensino-aprendizagem.

Quando a resposta esperada, disponibilizada pelo INEP, indica a necessidade de autonomia do aluno e o diálogo entre professores e alunos, pode-se atrelar esses conceitos à necessidade de formação de professores para o que os pesquisadores têm chamado de mediador. Moran, Masetto e Behrens (2013, p. 12) afirmam que "nosso papel fundamental na educação escolar é de ser mediadores interessantes, competentes e confiáveis entre o que a instituição propõe em cada etapa e o que os alunos esperam, desejam e realizam".

Ressalta-se que a questão apresentada na Figura 11 foi categorizada como Uso das TIC para o ensino de língua portuguesa por apresentar em seu enunciado a formação do professor de língua e o elemento-base trazer um diálogo que remete à aquisição da linguagem no contexto da cibercultura. Porém, a orientação para a resposta, fornecida pelo INEP, possibilitaria o enquadramento da questão na categoria próxima categoria a ser discutida, Uso das TICs para o ensino, por não trazer informações específicas voltadas para o ensino de língua portuguesa.

A categoria uso das TICs para o ensino foi indicada para três questões, sendo: no ano de 2008 uma objetiva de formação geral, apresentada na Figura 2; em 2011, uma questão objetiva de formação específica e, em 2014, uma objetiva no componente específico.

\footnotetext{
${ }^{5}$ Falas dos balões do primeiro texto: o primeiro passarinho: Pio, o segundo passarinho: Pio, o terceiro passarinho @Pio.
}

${ }^{6}$ A imagem da questão foi recortada e posicionada para melhor visualização, não houve alteração no conteúdo 
Inicia-se a análise pela questão apresentada na Figura 2 que, além da categoria em análise nesta etapa, também foi categorizada em inclusão/exclusão digital e cibercultura. Essa questão, no que diz respeito ao ensino, põe em discussão as tecnologias na educação, não especificamente voltadas para o ensino da língua portuguesa, mas em relação ao papel dos sujeitos do processo de ensinoaprendizagem, sendo necessário que se compreenda que "o uso do computador na educação tem um potencial enorme, que não está diretamente relacionado à presença da máquina, mas sim do professor" (BRITO; PURIFICAÇÃO, 2015, p. 112). A análise dos demais itens dessa questão será finalizada na categoria cibercultura que será discutida adiante.

Na segunda questão desta categoria, Figura 12, o aluno precisa responder a uma situação-problema que apresenta como mote o planejamento e o uso de tecnologias. De acordo com Brito e Purificação (2015, p. 111), “o uso planejado do computador na escola pode trazer modificações importantes nas formas de ação dos professores em sala de aula e no ensino de forma geral”, sendo assim, como qualquer outro equipamento, o uso dos computadores, ou o laboratório de informática, como traz a questão, precisa ser pensado desde a organização do currículo até os objetivos da disciplina, considerando as possibilidades tecnológicas à disposição, como é indicado na alternativa $a$ da questão.

Figura 12 - Questão de prova: ENADE 2011

QUESTĀO 29

Na escola em que João é professor, existe um laboratório de informática, que é utilizado para os estudantes trabalharem conteúdos em diferentes disciplinas. Considere que João quer utilizar o laboratório para favorecer o processo ensinoaprendizagem, fazendo uso da abordagem da Pedagogia de Projetos. Nesse caso, seu planejamento, o professor deve

( estabelecer como eixo temático uma problemática significativa para os estudantes, considerando as possibilidades tecnológicas existentes no laboratório.

B relacionar os conteúdos previamente instituídos no início do período letivo com os que estão no banco de dados disponível nos computadores do laboratório de informática.

C definir os conteúdos a serem trabalhados, utilizando a relação dos temas instituídos no projeto pedagógico da escola e o banco de dados disponivel nos computadores do laboratório.

D listar os conteúdos que deverão ser ministrados durante o semestre, considerando a sequência apresentada no livro didático e os programas disponíveis nos computadores do laboratório.

€ propor o estudo dos projetos concorrentes que foram desenvolvidos pelo governo ao uso de laboratório de informática, relacionando o que consta no livro didático com as tecnologias existentes no laboratório.

Fonte: INEP (2011d, p. 23).

A última questão desta categoria, Figura 13, retoma o que foi visto em questões anteriores, como a Figura 2 e a Figura 11. Um dos textos do elemento-base da questão traz a discussão sobre a conectividade generalizada, que será debatida na categoria cibercultura. Na categoria uso das TICs para o ensino, a discussão parte do uso das tecnologias na vida pessoal para entretenimento e a dificuldade apresentada para o uso pedagógico. Para Moran, Masetto e Behrens (2013) a disseminação 
do uso da internet teria um grande impacto nos primeiros anos com diferentes metodologias, porém, a expectativa de metodologias mais participativas e adaptadas a cada aluno, esperada pelo autor, acontece em um ritmo muito mais lento que o esperado.

Figura 13 - Trecho da questão de prova: ENADE 2014

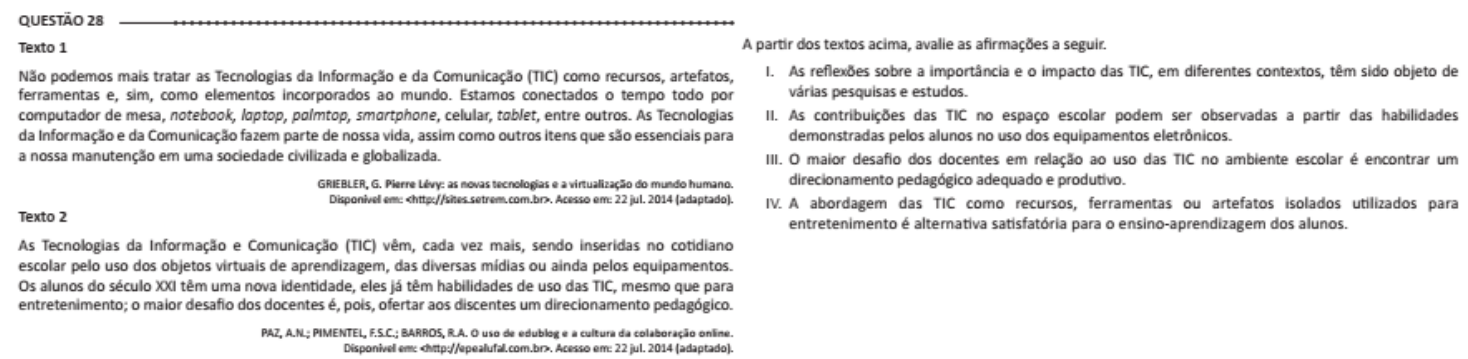

Fonte: INEP (2014d, p. 28).

Nos dois textos do elemento-base da questão, apresenta-se a realidade de uma sociedade tecnologizada e espera-se que o aluno participante do exame possa compreender as contribuições e desafios para o uso das TICs. Nesse caso, a questão evidencia a necessidade de formação docente a partir das dimensões de Garcia-Vera (2000), já apresentadas anteriormente, destacando-se a dimensão sociocultural uma vez que se espera do aluno a compreensão das formas como as pessoas se relacionam com as tecnologias.

Considerando o texto 1 do elemento-base dessa questão, ela também foi enquadrada na categoria cibercultura, que se discute a partir de agora.

A partir da análise das questões, a categoria cibercultura apareceu em nove questões objetivas, sendo: duas questões no ano de 2011, uma na seção de formação geral e a outra na de formação específica; cinco questões em 2014, dentre elas as já apresentadas nas Figuras 2 e 13, das cinco questões apenas uma é da seção de formação específica e, em 2017, são duas questões objetivas de formação específica, dentre elas a questão já apresentada na Figura 9.

Para a análise da categoria cibercultura, adota-se os estudos de Pierre Lévy e André Lemos. Para Lévy (2010, p. 17), cibercultura "é o conjunto de técnicas (materiais e intelectuais), de práticas, de atitudes, de modos de pensamento e de valores que se desenvolvem juntamente com o crescimento do ciberespaço".

Lemos (2003) cita três leis da cibercultura para que se possa analisar a sociedade contemporânea. A primeira é lei da Reconfiguração em que não se considera a substituição ou desaparecimento de mídias, práticas etc., mas sim em uma reconfiguração que não promove o aniquilamento dos seus 
precedentes. A segunda é a lei da liberação do Polo da emissão, que retrata a descentralização da informação da mão dos grandes meios de comunicação e permite que cidadãos comuns também informem, interajam, comuniquem sua opinião. A terceira é a lei da Conectividade generalizada que transformou o computador pessoal em um computador coletivo e, posteriormente, em computador coletivo móvel. A conectividade generalizada prevê o contato entre "homens e homens, homens e máquinas, mas também entre máquinas e máquinas que passam a trocar informação de forma autônoma e independente". A partir das considerações de Lévy (2010) e Lemos (2003), inicia-se a análise das questões da categoria cibercultura na prova do ano de 2011. A primeira questão de análise é da seção de formação geral, Figura 14.

Figura 14 - Trecho de questão: ENADE 2011

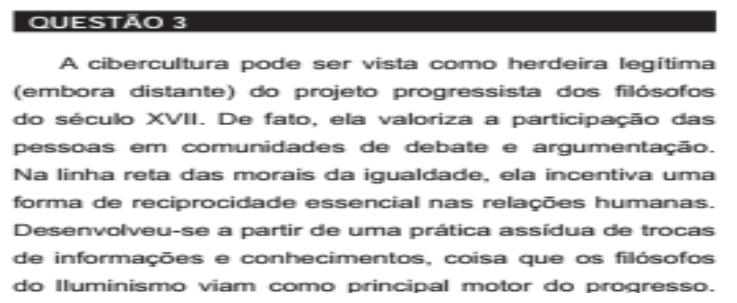

Fonte: INEP (2011d, p. 3).

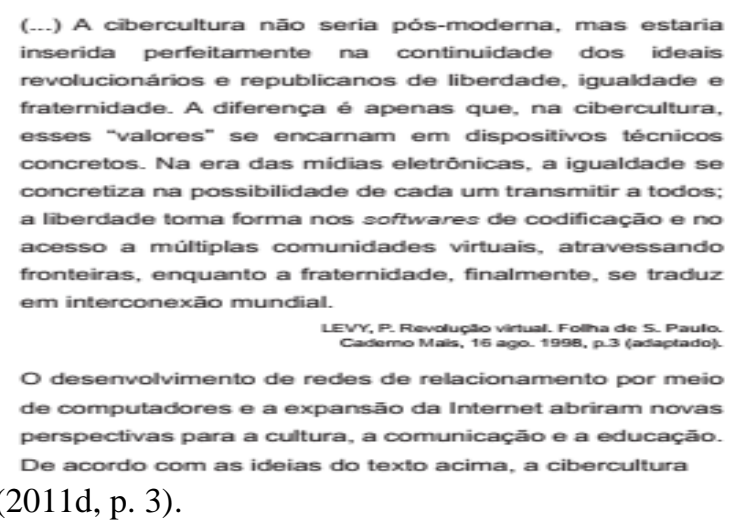

A questão solicita que o aluno apresente compreensão sobre a cibercultura a partir da análise de um texto fornecido como elemento-base, de autoria de Pierre Lévy, um dos autores norteadores do presente estudo. Vale ressaltar que o termo cibercultura não aparece em nenhum dos documentos do ENADE que antecedem as provas, ou seja, não consta nas diretrizes ou portarias do exame, razão pela qual foi uma categoria criada a partir das provas devido à ausência nos documentos, conforme relatado anteriormente. Destaca-se ainda que nas edições de 2005 e de 2008 não foram encontradas questões nessa categoria e que o texto fonte da prova de 2011, Figura 14, foi publicado em 1998, conforme indica a referência da prova.

A segunda questão da categoria (Figura 15), também do ano de 2011, é da seção de formação específica. Nesta questão, assim como a apresentada na Figura 2, é necessário que se tenha o conhecimento da lei da Reconfiguração, pois, assim como na alternativa correta (letra C), nos distratores $a, b$ e $d$ espera-se que o aluno compreenda que as novas tecnologias não substituirão as anteriores. O distrator $a$, por sua vez, também aborda o tema substituição. A alterativa poderia ser 
resolvida com o conhecimento sobre cibercultura, mas também, com os conhecimentos específicos relacionados à área de formação específica do curso de Letras, a linguística. Ciência que considera a língua em constante movimento, conforme afirma Bagno (2015, p. 168): “a língua é viva, dinâmica, está em constante movimento - toda língua viva é uma língua em decomposição e em recomposição, em permanente transformação" (grifo do autor).

Figura 15 - Trecho de questão: ENADE 2011
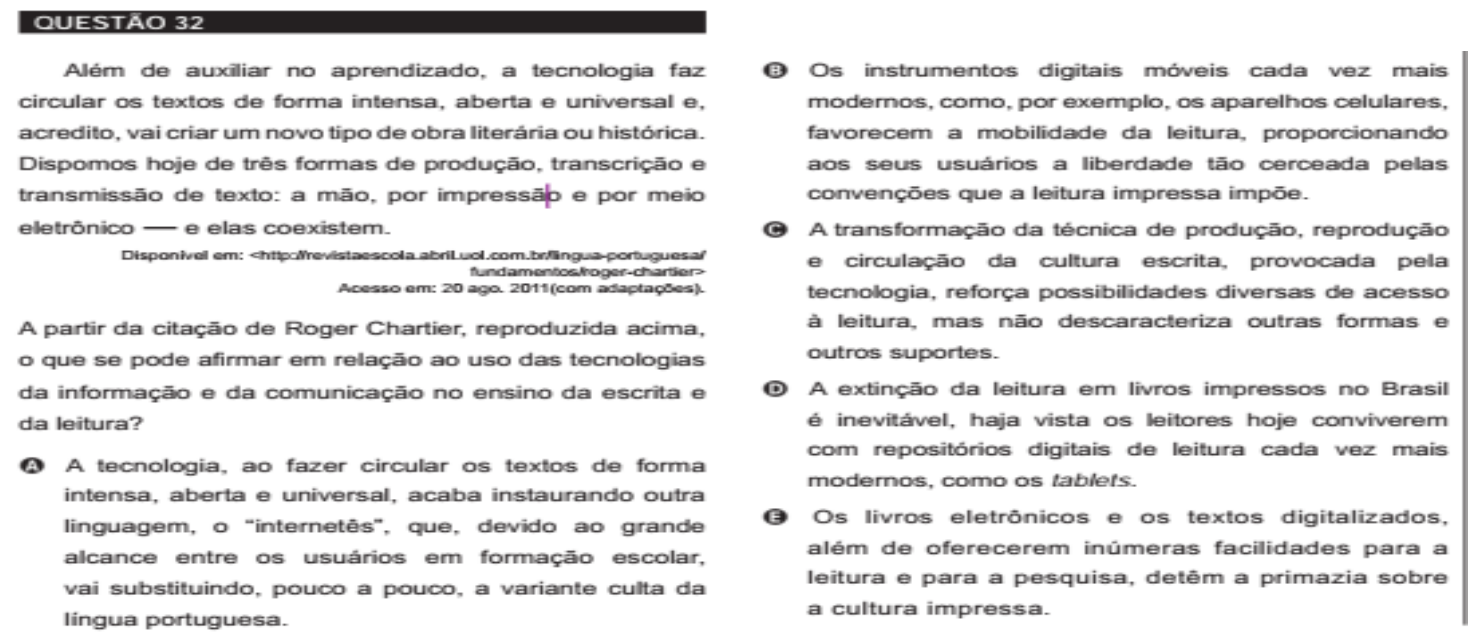

Fonte: INEP (2011d, p. 25).

A terceira questão de análise foi apresentada na Figura 2, os distratores $a$ e $e$ da questão exigem que o aluno conheça o conceito da lei da reconfiguração, citado por Lemos (2003), para que perceba que as inovações tecnológicas não tornarão obsoletos ou substituirão os saberes dos professores e que os acervos impressos das bibliotecas das escolas não devem ser substituídos pelos digitais.

Já a Figura 16 apresenta uma questão de razão e asserção em que se discute a mudança do polo da emissão, pois o texto apresentado como elemento-base relata a mudança do polo emissor ao dizer que em tempos digitais é possível publicizar uma música, um texto, uma exposição, sem que se passe pelo crivo de curadoria de várias pessoas, veículos de comunicação etc. 
Figura 16 - Trecho de questão de prova: ENADE 2014

\begin{abstract}
QUESTÃo 01
O trecho da música "Nos Bailes da Vida", de Milton Nascimento, "todo artista tem de ir aonde o povo está", é antigo, e a música, de tăo tocada, acabou por se tornar um esterétilipo de tocadores de violరles e de rodas de amigos em Visconde de Mauá, nos anos 1970 . Em tempos digitais, porém, ela ficou mais atual do que nunca. É fácil entender o porquê: antigamente, quando a informaçăo se concentrava em centros de exposiçăo, veiculos de comunicaçăo, editoras, museus e gravadoras, era preciso passar por uma série de curadores, para garantir a publicaçăo de um artigo ou livro, a gravaçăo de um disco ou a produçăo de uma exposiçăo. O mesmo funil, que poderia ser injusto e debxar grandes talentos de fora, simplesmente porque năo tinham acesso às ferramentas, às pessoas ou às fontes de informaçăo, também servia como filtro de qualidade. Tocar violåo ou encenar uma peça de teatro em um grande auditório costumava ter um peso muito maior do que fazê-lo em um bar, um centro cultural ou uma calçada. Nas raras ocasiőes em que esse valor se invertia, era justamente porque, para uso do espaço "alternativo", havia mecanismos de seleçăo tăo ou mais rigidos que os do espaço oficial.

RADFAHRER, L Todo artista tem de it aonde o povo estí.Disponfivel ems dittp://nevo.jtaucultural.org bo. Acosso ems 29 juL 2014 (adaptado).

A partir do texto acima, avalie as asserç̋̄es a seguir e a relaçăo proposta entre elas.

l. O processo de evoluçăo tecnológica da atualidade democratiza a produçăo e a divulgaçăo de obras artísticas, reduzindo a importância que os centros de exposição tinham nos anos 1970. PORQUE

II. As novas tecnologias possibilitam que artistas sejam independentes, montem seus próprios ambientes de produçăo e disponibilizem seus trabalhos, de forma simples, para um grande número de pessoas.
\end{abstract}

Fonte: INEP (2014d, p. 4).

Na questão já apresentada na Figura 10, também foi discutida a segunda lei da cibercultura atrelada ao processo de curadoria. Diferente da questão da Figura 16, que é de formação geral, a Figura 10, da seção de formação específica, discute a prática pedagógica do ensino de língua portuguesa partir a curadoria de uma playlist comentada. No elemento-base da questão, o texto de Rojane Rojo indica que é necessário pensar que a disponibilização do arquivo na internet pode acarretar em um processo de interação, a partir do compartilhamento e também com a ação de curtir. Por essa indicação, da possibilidade de compartilhamento, entende-se que o aluno é levado a refletir sobre a descentralização do polo emissor, segunda lei da cibercultura (LEMOS, 2003).

A Figura 17 apresenta uma questão da seção de formação específica do ENADE 2014, que tem como mote a leitura e a escrita em relação ao uso das TICs. Para que o aluno respondente entenda que as alternativas $a$ e $b$ são distratores, é importante que ele conheça a primeira lei da cibercultura, assim, poderá entender como falsa a ideia de que os leitores atuais substituíram a leitura de materiais impressos por tablets, bem como irá descartar a alternativa $b$ como correta por ter a compreensão de que o internetês não substitui outras formas da comunicação escrita. 


\section{Revista Docência e Cibercultura}

Figura 17 - Questão de prova: ENADE 2014

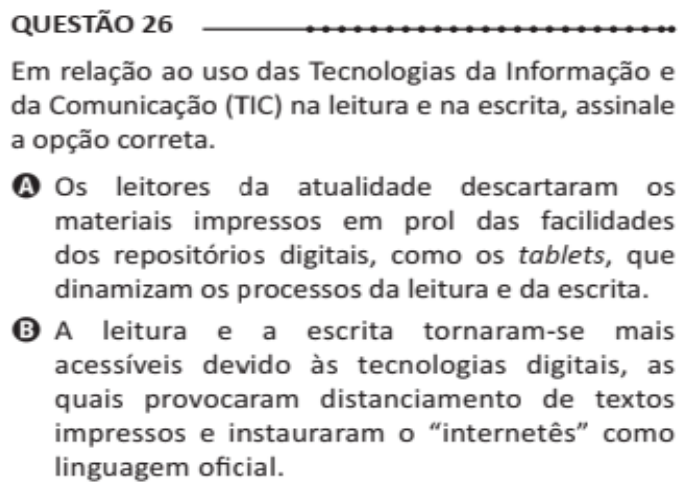

Em relação ao uso das Tecnologias da Informação e da Comunicação (TIC) na leitura e na escrita, assinale a opção correta.

A Os leitores da atualidade descartaram os materiais impressos em prol das facilidades dos repositórios digitais, como os tablets, que dinamizam os processos da leitura e da escrita.

B A leitura e a escrita tornaram-se mais acessíveis devido às tecnologias digitais, as quais provocaram distanciamento de textos impressos e instauraram o "internetês" como linguagem oficial.

C A diminuição das distâncias espaciais e temporais intensificou e diversificou os modos de comunicação e informação, flexibilizando a formação de leitores de modo mais abrangente e superficial.

D Os avanços tecnológicos promoveram mudanças significativas nos modos de ler e escrever, favorecendo, principalmente no ato da leitura, a capacidade de unir diferentes linguagens para a construção da significação.

E As mudanças proporcionadas pela tecnologia nas maneiras de ler, de produzir e de fazer circular textos nas sociedades desconsideram não só outras formas de ler e escrever, mas também outros suportes de circulação.

Fonte: INEP (2014d, p. 26).

Outra questão desta categoria que também menciona a web é a questão já apresentada na Figura 7 , que também remete à segunda lei da cibercultura: a mudança do polo da emissão (LEMOS, 2003), pois menciona a possibilidade da interação que vai além de quem publica o conteúdo, como acontece na redistribuição e compartilhamento de informações.

A próxima questão dessa categoria, apresentada na Figura 18, pertence à seção de formação geral do exame de 2014 e tem como tema as redes sociais, que é uma das categorias que ainda será analisada. A questão foi considerada também na categoria cibercultura porque, de acordo com Lévy

o ciberesperaço (que também chamarei de "rede") é um novo meio de comunicação que surge da interconexão mundial de computadores. $\mathrm{O}$ termo especifica não apenas a infraestrutura material da comunicação digital, mas também o universo oceânico de informações que ela abriga, assim como os seres humanos que navegam e alimentam esse universo (2010, p. 17).

Considerando a definição de Lévy para ciberespaço, pode-se inferir que reconhecer que esse espaço não é formado apenas por máquinas é essencial para a resolução da questão. Atrelada ao conhecimento do ciberespaço têm-se a lei da mudança do polo emissor, em que há uma facilidade de se manifestar, como prevê o elemento-base: “é inevitável que muita gente encontre nelas uma maneira fácil, rápida e abrangente de se manifestar" e da conectividade generalizada em que todos estão em constante contato, como também se vê no elemento-base em que 60\% das empresas "bisbilhotam a vida dos candidatos em websites de rede social" (INEP, 2014d, p. 6) 
Figura 18 - Questão de prova: ENADE 2014

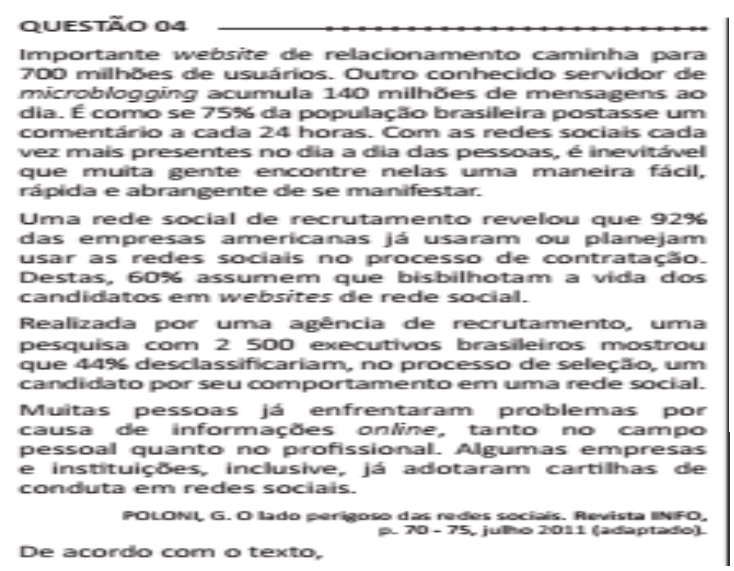

De acordo com o texto.

A mais da metade das empresas americanas evita acessar websites de redes sociais de candidatos a emprego.

B empresas e instituições estão atentas ao comportamento de seus funcionários em websites de redes sociais.

C a complexidade dos procedimentos de rastreio e monitoramento de uma rede social impede que as empresas tenham acesso ao perfil de seus

- as cartilhas de conduta adotadas nas empresas proibem o uso de redes sociais pelos funcionários, em vez de recomendar mudanças de comportamento.

\& a maioria dos executivos brasileiros utilizaria informações obtidas em websites de redes sociais, para desclassificar um candidato em processo de seleção.

Fonte: INEP (2014d, p. 6).

A questão apresentada na Figura 18 também foi classificada na categoria Redes sociais. Dentre os conceitos para rede social, o Dicionário Aurélio traz: "Inform. Grupo de usuários da Internet, ger. com interesses comuns, que se comunicam, através de um site, visando estabelecer relacionamento pessoal ou profissional" (2010, p. 1797). Ainda que a questão seja interpretativa, não sendo necessário conhecimentos específicos sobre o tema, a escolha do elemento-base se enquadraria na dimensão sociocultural, apresentada por Garcia-Vera. Essa dimensão, como dito anteriormente, está relacionada ao uso dos recursos tecnológicos e a modificação da forma como uma atividade é realizada, pois, de acordo com o texto apresentado para os contratantes, o comportamento de um candidato nas redes sociais pode ser motivo de desclassificação em um processo seletivo, lembrando que as dimensões citadas pelo autor são consideradas necessárias para a formação de professores.

A categoria EaD e tecnologia foi indicada em uma questão discursiva da seção de formação geral da prova de 2011, Figura 19. Nessa questão, o elemento-base afirma que "são necessárias tecnologias cada vez mais sofisticadas para essa modalidade de ensino", o texto afirma ainda que é necessária "uma pedagogia que se desenvolva por meio de novas relações de ensino-aprendizagem" (INEP, 2011d, p. 7). 
Figura 19 - Questão da prova: ENADE 2011

QUESTĀO DISCURSINA 1

A Educaçăo a Distancia $(E a D)$ é a modalidade de ensino que permilte que a comunicaçs̆o e a construçầo do conhecimento entre os usuários envolvidos possam acontecer em locais e tempos distintos. S\&o necessárias tecnologias cada vez mais sofisticadas para essa modalidade de ensino năo presencial, com vistas à crescente necessidade de uma pedagogia que se desenvolva por meio de novas relaçőes de ensino-aprendizagem.

O Censo da Educaçăa Superior de 2009, realizado pelo MECINEP, aponta para $o$ aumento expressivo do número de matriculas nessa modalidade. Entre 2004 e 2009, a participaçăo da EaD na Educaçăo Superior passou de 1,4\% para $14,1 \%$, totalizando 838 mil matriculas, das quais $50 \%$ em cursos de licenclatura. Levantamentos apontam ainda que $37 \%$ dos estudantes de EaD estão na pós-graduaçăo e que $42 \%$ estâo fora do seu estado de origem.

Considerando as informaçర̄es acima, enumere três vantagens de um curso a distâncla, justificando brevemente cada uma delas. (valor: 10,0 pontos)

Fonte: INEP (2011d, p. 7).

Para Moore e Kearsley (2008) apud Mill (2018, p. 199), "a ideia de EaD é muito simples: alunos e professores estão em locais diferentes durante todo ou grande parte do tempo em que aprendem e ensinam, comunicando-se por meio de tecnologias diversas".

Considerando o que traz o texto do elemento-base e a definição apresentada, infere-se que as tecnologias que a questão cita têm por intuito promover a interação, reduzindo a distância geográfica entre alunos e professores. O padrão de respostas disponibilizado pelo INEP menciona dez vantagens para $\mathrm{EAD}$, sendo sete relacionadas à possibilidade de acesso por meio da tecnologia, uma vez que mencionam o fato da localização geográfica, da flexibilidade do local e até mesmo a dificuldade de locomoção de pessoas com “comprometimento motor" (INEP, 2011a, p. 1).

A questão da Figura 19, embora não traga em seu comando a discussão da temática tecnologia, demanda que o respondente compreenda as possibilidades da educação a distância para que possa elencar as vantagens dessa modalidade de ensino. 
A última categoria deste estudo é a tecnologia como pretexto. Como já mencionado, a categoria emergiu da leitura das questões, especificamente, a partir da apresentada na Figura 20, uma questão objetiva da seção de formação específica da prova do ano de 2011.

Figura 20 - Questão de prova: ENADE 2011
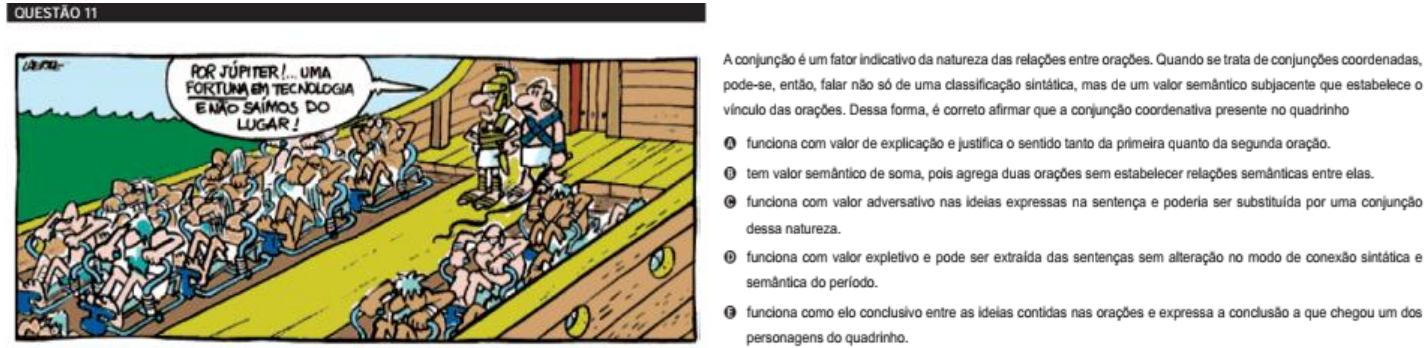

personagens do quadrinho.

Fonte: INEP (2011d, p. 10).

Como pôde ser visto na imagem, a charge é apenas um pretexto para uma análise sintática, diferente do que acontece, por exemplo, na questão da Figura $18 \mathrm{em}$ que, embora não fossem necessários conhecimentos acerca do tema tecnologia, era necessária a interpretação do texto no elemento-base.

A Figura 20 poderia ser discutida, por exemplo, a partir da dimensão econômico-laboral de GarciaVera (2000), mas também poderia ser discutida partindo da ideia, aqui já apresentada, de que a inserção de equipamentos na escola não significa a solução de todos os problemas da educação ou a melhoria do processo de ensino-aprendizagem.

\section{CONSIDERAÇÕES FINAIS}

A investigação proposta nesta pesquisa sobre o exame ENADE em relação às tecnologias educacionais nas provas do curso de Letras confirmou a existência de questões que abordam a temática.

A partir da análise das questões foi possível perceber que, desde a primeira edição do exame, houve um aumento quantitativo e também qualitativo em relação à presença do tema tecnologia nas questões aplicadas. Na primeira edição, em 2005, identificou-se duas questões na seção de formação geral que abordavam a temática que foi categorizada nesta pesquisa como Inclusão/exclusão digital e na edição de 2011 detectou-se sete questões em diferentes categorias, tanto na seção de formação geral como na específica. 


\section{Revista Docência e Cibercultura}

Outra constatação é de que há uma preocupação em discutir a tecnologia na formação de professores para além da inserção de equipamentos nos ambientes de ensino, pois a prova, em muitas questões, instigou o aluno a refletir sobre a relação entre o conteúdo, a tecnologia e a metodologia. Essa abordagem se deu tanto na escolha dos elementos-base das questões como na elaboração das alternativas corretas e distratores.

Ressalta-se que, embora os elementos-base tenham trazido uma diversidade de temas a serem explorados, identificou-se situações nas quais os textos foram pretextos de análise interpretativa de conteúdo ou, até mesmo, base para a discussão de elementos linguísticos, como pôde ser visto na categoria tecnologia como pretexto.

Como exposto no início deste estudo, pelo fato de não se ter um conceito de tecnologia adotado pelo exame, questões como a apresentada na Figura 6, que traz no elemento-base a discussão a partir de um folheto elaborado com "tecnologias diversificadas", sem que sejam mencionadas quais são ou o que se entente por tecnologia, podem ter sua compreensão prejudicada no momento da realização da prova.

Vale ressaltar que as questões do exame trouxeram para a discussão, explícita e implicitamente, a cibercultura que não é citada como tema nas portarias do exame, a presença da discussão sobre cibercultura nas questões reafirma que, de modo geral, a reflexão exigida na prova vai além da tecnologia física na escola.

Cabe esclarecer que, de forma alguma, acredita-se que o ENADE ou qualquer outro exame possa avaliar todo o conhecimento dos professores em formação, porém, uma vez instituído, cabe a análise do conhecimento dos estudantes temáticas pertinentes à formação de professores.

Diante do exposto, considera-se que houve um avanço nas propostas das questões que abordam a temática tecnologia educacional nos exames do ENADE para o curso de Letras com habilitação em língua portuguesa, porém, a partir deste estudo ficam as indagações se as reflexões instigadas nas provas também são temáticas abordadas em discussões dentro das instituições de ensino, planejadas a partir do currículo dos cursos.

\section{REFERÊNCIAS}

BAGNO, M. Preconceito linguístico. 56. ed. revista e ampliada. São Paulo: Parábola Editorial, 2015.

BARDIN, L. Análise de conteúdo. São Paulo: Edições 70, 2016.

BERTOLDO, H. L; MILL, D. Tecnologia. In: MILL, D. (Org.). Dicionário crítico de educação e tecnologia e de educação a distância. Campinas: Papirus, 2018. p. 596-606. 
BERTOLDO, H. L.; MILL, D. SALTO, F. Tecnologias de informação e comunicação. In: MILL, D. (Org.). Dicionário crítico de educação e tecnologia e de educação a distância. Campinas: Papirus, 2018. p. 617-625.

BRASIL, INEP. [O que é o ENADE]. Portal INEP. 23 ago. 2019. Disponível em:

<http://portal.inep.gov.br/web/guest/enade>. Acesso em: 28 ago. 2019.

BRASIL, INEP. Padrão de resposta prova ENADE 2005 Letras. Portal INEP, 2005 (a). Disponível em: <http://download.inep.gov.br/download/enade/2005/PR_letras.pdf >. Acesso em: 17 out. 2019. BRASIL, INEP. Padrão de resposta prova ENADE 2008 Letras. Portal INEP, 2008 (a). Disponível em:

<http://download.inep.gov.br/download/Enade2008_RNP/PADRAO_DE_RESPOSTA_DE_LETR AS.pdf>. Acesso em: 17 out. 2019.

BRASIL, INEP. Padrão de resposta prova ENADE 2011 Letras. Portal INEP, 2011 (a). Disponível em: <http://download.inep.gov.br/educacao_superior/enade/padrao_resposta/2011/LETRAS.pdf>. Acesso em: 17 out. 2019.

BRASIL, INEP. Padrão de resposta prova ENADE 2014 Letras Português Licenciatura. Portal INEP, 2014 (a). Disponível em:

<http://download.inep.gov.br/educacao_superior/enade/padrao_resposta/2014/padrao_resposta_letra s_portugues_licenciatura.pdf $>$. Acesso em: 17 out. 2019.

BRASIL, INEP. Padrão de resposta prova ENADE 2017 Letras Português Licenciatura. Portal INEP, 2017 (a). Disponível em:

<http://download.inep.gov.br/educacao_superior/enade/padrao_resposta/2017/Pad_Resp_Letras_Por tugues_Licenciatura.pdf>. Acesso em: 17 out. 2019.

BRASIL, INEP. Portaria $\mathrm{n}^{\circ} 131$, de 07 de agosto de 2008. Define as diretrizes da prova do ENADE de Letras 2008. Portal INEP, 2008 (b). Disponível em:

<http://download.inep.gov.br/download/superior/enade/Diretrizes\%20Enade/Diretrizes_Letras_\%20 n_131.pdf >. Acesso em: 17 out. 2019.

BRASIL, INEP. Portaria $\mathrm{n}^{\circ} 175$, de 24 de agosto de 2005. Define as diretrizes da prova do ENADE de Letras 2005. Portal INEP, 2005 (b). Disponível em:

<http://download.inep.gov.br/download/enade/PORTARIAS_ENADE_2005/Letras.pdf>. Acesso em: 17 out. 2019.

BRASIL, INEP. Portaria ${ }^{\circ}$ 188, de 12 de julho de 2011. Define as diretrizes de formação geral da prova do ENADE 2011. Portal INEP, 2011 (b). Disponível em:

<http://download.inep.gov.br/educacao_superior/enade/legislacao/2011/diretrizes/diretrizes_formac ao_geral_n_188.pdf>. Acesso em 17 out. 2019.

BRASIL, INEP. Portaria ${ }^{\circ} 222$, de 26 de julho de 2011. Define as diretrizes da prova do ENADE Letras 2011. Portal INEP, 2011 (c). Disponível em

<http://download.inep.gov.br/educacao_superior/enade/legislacao/2011/diretrizes/diretrizes_letras_n 222.pdf>. Acesso em: 17 out. 2019.

BRASIL, INEP. Portaria $\mathrm{n}^{\mathrm{o}} 255$, de 02 de junho de 2014. Define as diretrizes da prova de formação geral do ENADE 2014. Portal INEP, 2014. Disponível em:

<http://download.inep.gov.br/educacao_superior/enade/legislacao/2014/formacao_geral/formacao_g eral_portaria_n_255_02_junho_2014.pdf>. Acesso em: 17 out. 2019.

BRASIL, INEP. Portaria ${ }^{\circ} 258$, de 02 de junho de 2014. Define as diretrizes da prova do ENADE de Letras 2014. Portal INEP, 2014 (c) Disponível em:

<http://download.inep.gov.br/educacao_superior/enade/legislacao/2014/formacao_geral/formacao_g eral_portaria_n_255_02_junho_2014.pdf >. Acesso em: 17 out. 2019.

BRASIL, INEP. Portaria $n^{\circ} 493$, de 06 de junho de 2017. Define as diretrizes da prova de formação geral do ENADE 2017. Portal INEP, 2017 (b). Disponível em: 
<http://download.inep.gov.br/educacao_superior/enade/legislacao/2017/formacao_geral__portaria_n_493_de_6_de_junho_de_2017.pdf>. Acesso em: 17 out. 2019.

BRASIL, INEP. Portaria n ${ }^{\circ}$ 504, de 06 de junho de 2017. Define as diretrizes da prova do ENADE de Letras 2017. Portal INEP, 2017 (b). Disponível em:

<http://download.inep.gov.br/educacao_superior/enade/legislacao/2017/formacao_geral__portaria_n_493_de_6_de_junho_de_2017.pdf>. Acesso em: 17 out. 2019.

BRASIL, INEP. Prova ENADE 2005 Letras. Portal INEP, 2005 (c). Disponível em $\langle$ http://download.inep.gov.br/download/enade/2005/provas/LETRAS.pdf >. Acesso em: 17 out. 2019.

BRASIL, INEP. Prova ENADE 2008 Letras. Portal INEP, 2008 (c). Disponível em: <http://download.inep.gov.br/download/Enade2008_RNP/LETRAS.pdf>. Acesso em: 17 out. 2019. BRASIL, INEP. Prova ENADE 2011 Letras. Portal INEP, 2011 (d). Disponível em: <http://download.inep.gov.br/educacao_superior/enade/provas/2011/LETRAS.pdf>. Acesso em: 17 out. 2019.

BRASIL, INEP. Prova ENADE 2014 Letras Português Licenciatura. Portal INEP, 2014 (d).

Disponível em:

<http://download.inep.gov.br/educacao_superior/enade/provas/2014/30_letras_portugues_licenciatu ra.pdf>. Acesso em: 17 out. 2019.

BRASIL, INEP. Prova ENADE 2017 Letras Português Licenciatura. Portal INEP, 2017 (a).

Disponível em:

<http://download.inep.gov.br/educacao_superior/enade/provas/2017/31_LET_POR_LICENCIATU RA_BAIXA.pdf >. Acesso em: 17 out. 2019.

BRITO, G. da. S; PURIFICAÇÃO, I. Educação e novas tecnologias: um repensar. 2. ed. Curitiba: Intersaberes, 2015.

CONSELHO NACIONAL DE EDUCAÇÃO. Diretrizes Curriculares Nacionais dos cursos de Filosofia, História, Geografia, Serviço Social, Comunicação Social, Ciências Sociais, Letras, Biblioteconomia, Arquivologia e Museologia. Parecer CNE/CES 492/2001. Relator: Silke Weber. Distrito Federal. Disponível em: <http://portal.mec.gov.br/cne/arquivos/pdf/CES0492.pdf>. Acesso em: 02 fev. 2019.

CONSELHO NACIONAL DE EDUCAÇÃO. Institui Diretrizes Curriculares Nacionais para a Formação de Professores da Educação Básica, em nível superior, curso de licenciatura, de graduação plena. Resolução CNE/CP 1, de 18 de fevereiro de 2002. Disponível em:

<http://portal.mec.gov.br/seesp/arquivos/pdf/res1_2.pdf>. Acesso em: 02 fev. 2019.

CORRÊA, H.; COSCARELLI, C. Multimodalidade. In: MILL, D. (Org.). Dicionário crítico de educação e tecnologia e de educação a distância. Campinas: Papirus, 2018. p. 467-470.

FERNANDES, J. R.; BRAGA, F. M. Inclusão digital. In: MILL, D. (Org.). Dicionário crítico de educação e tecnologia e de educação a distância. Campinas: Papirus, 2018. p. 333-336.

GARCÍA-VERA, A. B. Tres temas tecnológicos para la formación del professorado. n. 322, p. 167$188,2000$.

GIL, A. C. Métodos e técnicas de pesquisa social. 6. ed. São Paulo: Atlas, 2008.

KENSKI, V. M. Educação e novas tecnologias: o novo ritmo da informação. 8. ed. Campinas: Papirus, 2012.

LEMOS, A. Cibercultura. Olhares sobre a Cibercultura: alguns pontos para compreender a nossa época. Porto Alegre: Sulina, 2003.

LÉVY, P. Cibercultura. Tradução de Carlos Irineu da Costa. São Paulo: Editora 34, 2010.

MILL, D. Educação a distância. In: MILL, D. (Org.). Dicionário crítico de educação e tecnologia e de educação a distância. Campinas: Papirus, 2018. p. 199-203. 
MORAN, J. M.; MASETTO, M. T.; BEHRENS, M. A. Novas tecnologias e mediação pedagógica. 21. ed. Campinas: Papirus, 2013.

SALDAÑA, J. The coding manual for qualitative researchers. Los Angeles: SAGE, 2016.

REDE SOCIAL. In: FERREIRA, A. B. de H. Novo dicionário Aurélio da língua portuguesa. 5. ed. Curitiba: Ed. Positivo, 2010. p. 1796-1797. citação dos autores e da fonte original e sob a mesma licença. 